\title{
REVIEW OF THE LEGAL PRINCIPLES OF QISAS IN IMAMIEH JURISPRUDENCE: AN EMPHASIS ON AYATOLLAH KHOYI'S POINTS OF VIEW
}

\author{
Afshaneh Ahmadi ${ }^{1}$ \\ Sayyed Mahmoud Majidi ${ }^{2}$ \\ Davood Dadashnezhad ${ }^{3}$
}

\begin{abstract}
One of the most significant functions of the Qisas (retribution) law is to protect human beings lives as well as their integrity. Approving and execution of the said punishment is subject to several requirements where the lack of any of them can prevent its execution. It is worth observing that the impediments of execution, delaying and even fall and amnesty of retaliation has got a great importance in the Islamic punishment laws and regulations. These laws are originated from the famous fatwa of the Shi'i jurisprudents, but are not separately and independently classified under a particular title. This article seeks to review and reveal all circumstances in which the said punishment is set aside in spite of the commitment of the murder
\end{abstract} and the crime. In this research, this issue has been examined from the perspective of the famous jurists of Imamieh comparing with the views of Grand Ayatollah Khoyi as well as Islamic Penal Code.

Keywords: Retribution, punishment, murder, justice, Islamic Penal Code.

\section{Introduction:}

One of the main goals of the Sharia of Islam and other divine religions is to provide justice which is the basis of all religious laws and regulations, especially on the subject of social relations of human beings. According to Islam, the principle of counteracting has

\footnotetext{
${ }^{1} \mathrm{PhD}$ student, Department of Islamic Jurisprudence, Damghan Branch, Islamic Azad University, Damghan, Iran. Email: majidi@du.ac.ir

${ }^{2}$ Assistant Professor, Department of Islamic Jurisprudence, Damghan Branch, Islamic Azad University, Damghan, Iran. Email: majidi@du.ac.ir

${ }^{3}$ Assistant Professor, Department of Islamic jurisprudence and slamic law, Damghan branch, Islamic Azad University, Damghan, Iran. Email: majidi@du.ac.ir
} 
been accepted as a primary principle dealing with the offenders while observing full equality between the offense and the punishment in the punishment of the intentional murder as the simplest and most basic concept used in criminal justice.

When it comes to criminal justice and it is interpreted according to proportionality between crime and punishment, the fairest punishment is the one which is more proportionate to the crime. It is so obvious that the last degree of proportionality will be shown when the outputs of crime and punishment are the same in terms of the similarities and externalities. So, retribution would be the fairest punishment that can be considered for that crime. For this reason, one of the main conditions of retaliation in Islam is the possibility of equality between the offense and the punishment, and if there is no possibility of observance of this equality or even if punishment has more severe effects than the crime, retaliation will not be executed. The issue of abolition of retaliation is as important as the retaliation of retribution because both cases relates to the life of human beings.

This article seeks to find answers to questions such as which conditions have to be met to prevent the retribution? And what are the differences and similarities between the opinion of the famous jurists of Imamieh and ayatollah Khoyi regarding the fall of Qisas and its prevention? Therefore, through applying the library method and referring to the jurisprudential texts, the opinions of the famous jurists of Imamieh are presented and compared to the opinions of the jurists and ultimately compared to the laws and regulations of the Islamic Penal Code of Islamic Republic of Iran.

\section{1- Murderer Madness}

One of the conditions for Qisas is equality between the murderer and the victim in terms of wisdom, so the lack of this equality will result in the removing of retribution. But the distinguishing the exact nature of madness is difficult, and scholars and jurists have not the same opinion about that.

\section{1-1- Being mad as Committing the Crime}

According to the opinion of the jurists of the Imamieh, if a mad person kills a wise or mad person, will not be 
killed, whether he has been permanent or periodic mad. If he commits the crime as being mad, he will not be punished because there is no intention but Agheleh $^{4}$ has to pay for it, All the jurists unanimously have the same idea about it (Marashi Najafi, 1995).

Therefore, wisdom and insanity are quite important for criminal responsibility. Late Imam Khomeini says: "The fourth condition for Qisas is being wise and matured, so the murderer who is mad right now will not be killed, no difference between the case being mad as committing the crime or not, and the Agheleh has to pay for it. (Khomeini, 1989).

The Javaher author says: Relying on both types of "Manghoul" and "Mohassal" consensus "Do not kill the mad for murder, no difference he is permanent or periodic, and no difference the victim is wise or mad. There are general Hadiths such as Hadith "Rafee" and etc, and specific other Hadith on it. If a mad person kills a wise or mad person, will not be killed, but Agheleh has to pay for it. Because the intentional

\footnotetext{
4 - kinsman; a certain relatives of offender who are responsible for payment of bloodmoney in non-intentional offences ; certain paternal relations of an offender who are
}

actions of a mad considered as wrongful and if there is no Agheleh, "Beit-al mal" has to pay for it as "Al- mohazab", "Jamee" and "Al- nahayeh" state.

Ayatullah Khoyi says: "If the murderer is insane, he will not be retaliated, no difference the victim is wise or insane, but Agheleh has to pay for it. The criterion for the unreliability of retaliation is being insane at the time of committing the crime (Najafi, 2013).

\section{1-2- The Murderer Become Mad after Committing the Crime}

If a wise and matured person commit intentional murder and becomes mad after that criminal offense, the retribution will not be canceled; therefore, the insanity which occurs after the crime will not have effect on responsibility, since the validity of the criminal liability has been complied with as committing the intended murder. In this regard, there is no difference between the jurists of the Imamieh, and it does not matter whether the retaliation

jointly responsible for payment of blood money in no intentional offences, certain paternal relatives of murdered 
is due to a confession or testimony of witnesses. The view of some jurisprudents is as follows:

Late Imam Khomeini says in this regard: "If a wise kill someone, then he becomes insane, he will be punished, whether the crime has been proved by "Bayeneh"(reason) or by his confession in his healthy status " (Khomeini, Same).

The reasons given by the jurists are as follows:

The "Barid Ajali quotes: Imam Sadiq (AS) was asked about a man who had deliberately killed a man but was not punished $^{5}$, and the testimony was not right against him. After he become mad, it was testified that he was murderer. Then another group testified against him that, after his madness, he committed the crime. Imam stated that whenever it is testified that he had done it as he was wise, he would be punished, and if they did not give such testimony, If he can afford, he has to pay to the victim's heir, and if he cannot afford, " Beyt Al-Mal" will pay for it, since Muslim lives will not be wasted (Horr Ameli, 1989).

Ayatollah Khoyi says: "If at the time when he was wise, he commit the

\footnotetext{
5 - fixed/ definite punishment; punishment exactly defined by sharia which may neither be reduced nor augmented; prescribed
}

crime and after the assassination, suffers from insanity, he will be punished. $\mathrm{He}$ also believes that" if the murderer is insane and then he has improved and become wise and Agheleh claim that the crime occurred at the time when the offender had a mental health, but the accused claims that the crime was in his state of insanity, the victim's claim would be accepted with his oath. Of course, if the offender does not have a history of insanity, it is up to him to prove this allegation, otherwise, the claim of the Agheleh with his oath will be accepted on the absence of psychological madness (Khoyi, 2013).

\section{1-3- Intentional Murder of Insane:}

Everyone who killed the sane would not be punished. Because one of the conditions for punishment is the perfection of wisdom in the murderer and the victim of both sides. Since there is no equality between the murderer and the victim, this inequity in the intellect will prevent the murderer's punishment. (Tusi, 1980) .

punishment; an unalterable punishment prescribed by religious 
But if a wise man kill an insane, although he is a periodically insane, the murderer has to pay, in the case of deliberate and quasi intentional but in the case of accident murder Agheleh is responsible, but if the insane attack to the wise and wise kill him there is no Qisas and Diyah and the" Beit El-mal" of the Muslims will pay for it. There is, of course, no dispute among the jurists that the wise is not retaliated for killing the insane, and even the "Kashf Al-Rumoz" has made a consensus on this ruling. According to this, there is a Hadith from "Abbi Bassir", which quoted that the Imam said: "... and if someone kill the insane and it is not due the attack of the sane, there is also no retaliation (Fadhil Lankarani, 2000). If the murderer is a kid or a insane, there will not be retribution again because of the Hadith of "Rafee".

\section{2- Murderer's Maturation}

First opinion: If a child committed murder, he would not be retaliated. Generally, maturity is one of the conditions for the punishment, so the immature child is not killed for killing someone. The late Sheikh Mohammad Hassan Najafi, the authour of the "Javaher al-Kalam", writes: the intentional and wrongful acts of the kids are the same; in other words, the intentional act of the kid is his fault (Najafi, 2013).

Allameh Helli in the "Mokhtasar" (Mohaqiq Heli, 1997) and in "Sharayee" (Mohaqiq Heli, 1988), Mohaqiq Heli in "Tabsareh" ( tabserat-al - motaalemin fi ahkame al-din,), Najafi in "Javaher-el-Kalam" (Najafi, 2013), And Imam Khomeini, in "Tahrir alWasilah" (Khomeini, 1989), they all believe that the child, as long as he is not adult, is not sentenced to death, and "Shahid Thani" in "al-Ruzat al-Bahyah" (Shahid Thani, 1990) says: the discerning child, is not killed for murder, but Agheleh has to pay for it." Sheikh Tousi" in his book called "Al-khalaf" has claimed a consensus for non-retribution of the child (Tusi, 1987).

The second opinion: If the child reaches the age of ten, he will be sentenced for the deliberate murder: the authour of the Javaher in the deliberate murder has claimed that Ghazi Ibn alAba'raj in "Mohazab" and "Javaher alFiqah" has accepted this view (Najafi, 2013).

Ibn Idris said in "Sara'er": If a child reaches the age of 10 , he will be retaliated and he will not be considered 
under Hadith of "Rafee". Elsewhere, in the same book, he writes: According to the correct Hadith, and what is said to be evidentiary, the intentional and wrongful acts of the child are the same, whether under 10 years of age or over 10 years (Ibn Idriss, 1990).

Third opinion: If the child height reaches five span, he will be sentenced to retaliation in the case of a deliberate murder: Sheikh Mufid has taken this opinion in" al-Muqnah". It was also said in the "Kashf Al-Letham" the "Fazil Hindi" that "Shaykhine, Saduqin" and another group have acted in this way (Horr Ameli, 1989).

Imam Sadiq (AS) said: Imam Ali (as) was asked about the adult and the child who had killed another one jointly, he answered: whenever a child height reaches five span, he will be retaliated, otherwise Agheleh will pay for it. Shahid Thani wrote in "Masalek al-Afham" that these Hadiths, which indicate that the child is retaliated if he reaches 5 span, not only are so weak but also so rare. In addition, it is against the principles of consensus of Muslims (Shahid Thani, 1990).

"Suleiman Bin Hafs" and "Hassan ibn Rashid" from Imam Hasan Asgari (AS) have narrated that the child whenever he reaches the age of eight, is allowed to control his assets and it is obligatory for him to be bound by the rules and regulations.

"The author of the Javaher" while quoting the above Hadith stated that: I did not find anyone to act on this Hadith. However, the child's deliberate acts are considered to be a pure wrongful, and Agheleh has to pay for it until he reaches the age of 15 (Najafi, 2004).

Fourth opinion: If a child become matured, he will be retaliated in case of growth. In contrast to the famous Imamieh jurists, another comment is also found in the works of some of the great jurists in this regard, referred to "Growth as a condition".

The author of Javaher says: "No one kills a child because he has killed a child or an adult. According to the famous Hadith and according to this principle maturity is the condition of retaliation. Some jurists have claimed consensus on it.

Ayatullah Khoyi believes that if a minor has committed a crime such as murder or injury, and then become maturd is not retaliated, but Agheleh will pay for it. Because the deliberate acts of minors are considered as wrongful, and 
also in the "Sahiheh Muhammad bin Muslim" of Imam Sadiq (a) that he said: "The delibrate and error of the child are the same, and in the "Motabareh" of "Ishaq bin Ammar" from "Ja'far" from his father Imam Ali (pbuh) said that Agheleh has to pay for all deliberate acts of the child (Khoyi, 2013).

\section{3- While the Victim is Mahdoraldam $^{6}$}

"Mahdur" is derived from root of "Hadar", meaning "waste" and "aldama" means blood; therefore, Mahdur al-Dam is one who has been killed and there is no retaliation. In other words there is no compensation for this murder. In the jurisprudential books, the definition of Mahdor al-Dam is expressed in general terms and in the form of the rule of law, as follows: one whose life and safety is not protected by the Shariah " (Mohaqiq Heli, 1988). Others have stated this as follows: (Khoyi, 2013) The rule is that killing him is permissible for the killer.

Mahdur al-Dam is divided into two categories: An absolute Mahdur al-

\footnotetext{
6 - one whose life and safety is not protected by the law; unprotected outlaw; to be killed with impunity; deserving death
}

Dam, who is considered to be a criminal against all people. Some groups has called it "intrinsic" like the infidel deserving to be fought with, apostate and "sub-al-Nabi"(who assault the prophet). The second category is called "Relative" Mahdur Al-Dam, which means just certain person or persons are allowed to prosecute it not all the people, because of the nature of the crime such as intentional murder which does not relate to all people; in other words it means there is legal immunity which prevent others to prosecute. Some other called it non- intrinsic Mahdur Al- dam.

In the opinion of the jurists of the Imamiyah, the practice of most jurists is to mention apostasy at the end of the chapter of "Had" and there is no mention of the apostate punishment. If the punishment of apostasy is not considered as "Had", the execution of the apostasy will be in the hands of the ruler, and unlike Sab al-Nabi, only Imam or Imam's vice may execute the apostasy punishment. As in the words of the jurists, the necessity of executing the apostasy is emphasized by Imam or the deputy of the Imam. 
"Shahid Aval's" believes that the apostate could be punished by Imam (AS) or the deputy of the Imam. Also, by virtue of the division of Mahdor al-Dam into "absolute" and "relative", the natural apostasy is considered to be relative Mahdor al-Dam, which is only, could be punished by Imam (as) or the deputy of the Imam. "Shahid Aval" has brought the apostate along with the cases of retribution and aggression (Khoyi, 2013).

It is understood from the Hadiths of the apostasy that it is kind of relative Mahdur Al- Dam. In this regard, in spite of the appropriation under the title of, in his book "Wasaeal-Shi'a", seven Hadiths of the Imams (AS) are quoted, and only in the third hadith of this book by Imam Sadiq It is quoted as saying: "Any Muslim shall be apostate among Muslims and deny the Prophet of Islam and his prophecy; it is quite lawful for anyone who hears to kill him." But in the following Hadith of Imam Ali says: "And it is upon Imam to kill and does not repent him." In the first hadith, it says: "Anyone who denies the prophecy is an unbeliever, and it is allowed to kill him."

\footnotetext{
7 - one whose life and safety is protected
} by the law
Under the same hadith, he says: "Anyone who wants to kill a Muslim or steal his assets, it is allowed to kill him." In other words, the Prophet (pbuh) allowed a Muslim to kill someone to defend himself. But in the first part of the Hadith he does not mention it is allowed for every man to kill apostate (Horr Ameli, 1989). In the rest of the hadiths concerning the punishment of apostate it is said: which means "it is allowed to kill" by Imam (AS) or the deputy of the Imam (Horr Ameli, 1989).

\section{4- While the Victim is Mahghon al- $\operatorname{dam}^{7}$}

The famous view of the Shi'a jurisprudents is that if one observes his wife in adultery with stranger and has been assured of the satisfaction of his wife to that adultery, he is allowed to kill his wife. However, some jurists such as Sheikh Toosi and Ibn-Idris, in addition to her satisfaction, have also considered "Ehsan" which means both sides being married (Najafi, 2013). But some contemporary jurisprudents have not 
accepted the famous belief and rejected it.

Ayatollah Khoyi, in "Mabani al-Takmeleh Al-Mannhaj", states: The famous belief is that if one observes a person with his wife in adultery with her satisfaction, he can kill both, but this famous idea is problematic and can be rejected (Khoyi, 2013).

In his rejection of the wellknown evidence, he refers to several Hadiths as follows:

1. According to Sa'id bin Masayeb's Hadith, he wrote to Abu Musai Ash'ari that Ibn Abi Jizerin had seen a man with his wife and killed him. In this case, ask Imam Ali (as). Abu Musa says: I met Ali (AS) and asked him and Imam Ali (AS) said: "My judgment is that if he brings four witnesses for what he has seen, I will not kill him otherwise I will punish him (Horr Ameli, 1989).

\section{2- Fatah bin Yazid Jarjani} stated that I asked Imam Ali (AS) about a man who has entered another house for theft or adultery and has been killed. The Prophet (sa) said: someone who inters other's house with no permission, his life is not legally protected and we do nothing with the murderer (the same, 70/29).
3- In Sahih Halabi, Imam Sadiq (AS) said: "If a person inters someone's house with no permission and looks at the house lord, there is no retaliation if they injure him or make him blind (Horr Ameli, 1989).

Ayatollah Khoyi rejects the famous belief and stated: The second hadith is not acceptable due to the existence of some unknown narrators, and in terms of implication, the subject of narration is where someone interred other's home for rubbing or committing other crimes and because of defense it is permitted to kill him,. Therefore, the assumption of authenticity is not at issue.

\section{5- Murder in the Case of Defense}

According to Shia unanimous jurisprudents, if someone is committing murder in the defense of one's self, one's possessions or honor, in case there is no way except murdering, he is not retaliated because the one who attaks is Mahdor al-dam

In the view of the Imamieh, defending life, property and honor are permitted and the attacker's life is wasted. "Mohaghegh" writes in "Shariah": For Muslim, defending life, property and honor are permitted as 
much as possible, and it is obligatory to defend as that much as needed (Mohaqiq Heli, 1988) .

The author of the Javaher in the description of Mohaghegh and endorsing the relevant consensus and principle, stated: "There is no problem in the license of absolute defense, but in "Kashf Al-letham" it is stated that if he is able to defend others' lives, in case of keeping himself safe, defense is obligatory (Najafi, 2013).

According to the famous Imamieh belief the defense of the lives, property and honor is an obligation. Shahid Thani writes in "Masalek' that: There is a strong belief that states "to defend the life and the privacy is an obligation", and if it is not possible to defend, escape is obligatory. But in the case of defense of property and assets, if it is a strong chance that he will not be killed, defense of the property is obligatory (Shahid Thani, 1990). Therefore, when the defense against the attker is obligatory or lawful, in the case of murder or assault, the defender is not responsible and the attacker's life is wasted. The one who has been attacked again is entitled to defend.

According to the Shi'i jurisprudents, we do not have any reason to condemn any kind of "Mohareb" and it is considered as relative Mahdour aldam. Basically, there is no definite punishment for a person who fights against Islam (Baghi), but, if the Imam (as) orders, Muslims are obliged to fight those who have come to confront the Imam (AS) or the Islamic government. Therefore, there is no specific penalty (Hadd) for the crime of insolence, to say that it is Mahdur Al-Adam like the murder. Shahid Thani in "Sharhe Lomeh" says: "A person who invades one of the Imams (AS) is a reber, whether one person, such as Ibn Muljim or more like the people of "Jamal" and "Safin", and it is in the discretion of the Imam to fight with the rebers until surrending to Imam's or murder (Shahid Thani, 1990).

Regarding the mohareb in Shi'a jurisprudential books, there is no reason for punishment of the mohareb without the permission of the Imam. What has been said in our jurisprudential texts is defense against the mohareb, and there are many Hadiths regarding the necessity of defense against plundering (Horr Ameli, 1989).

The Author of Javaher quotes some of these Hadiths as saying: "These hadiths are used as not distinguished 
between the defenses against the mohareb and plundering. Then he states there must be proportionality in respect the punishments and the attack (Najafi, 2013).

According to the Shi'a jurisprudence, mohareb and plunder are not generally considered to be absoloute Mahdur al-Dam, and as mentioned, their punishment would be set by Imam (as) or the ruler of Islam, It is obligatory on the ordinary people just to defend and If it leads to murder, there is no punishment.

\section{6- Murder in Drunkenness}

Another condition which has to be met for retaliation is that murderer must not be in drunk state. Because the drunk person cannot understand the goodness of his actions, so we are wondering whether such a person can be held responsible. In spite of the jurists' belief that a drunk person has no deliberate and arbitrary, there are disagreements about his punishment.

If anyone killed others in drunk state, is he retaliated? There is doubt and disagreement. But the proper principles and rules indicates that he is retaliated. Most believe in it. Shahid Thani said in "Masalek": Shahid in "Ghayat al-Murad" attributed this belief to "Ashab", and he refers to a consensus on that. Fakhr alMohagheghin has brought this subject to the debate about taking a hypnotic medicine.

Sheikh and others have said that the drunk and non-drunk are the same in terms of rules and regulations. Therefore, if someone voluntarily drinks wine and lose his discretion, then according to the rule of "that is, everyone who has the power to lose his authority volantreely treated as ones who have power. Even his wife's divorce is considered correct (Najafi, 2013). On the other hand, some other jurists such as Shahid Thani in Masalek "(Shahid Thani, 1990) believes that there is no Qisas.

There is a third opinion that Sheikh Tusi has narrated this Hadith with the following phrase: "A group of people drink, and they got drunk and kill each other with knife". Therefore, the appearance of this phrase implies that the conflict leads to murder, which is the habit of being drunk, and then the correct narration of Muhammad b. Qays is not in conflict with it because this Hadith is related to a special incident and should be interpreted for accidental murder. Assuming that there is conflict between 
these two Hadiths, so the one which is supported by the principle and rules must be accepted. It is understood that all three opinions are derived from hadiths; those who do not perceive retaliation have allegedly referred to the Hadith of Muhammad ibn Qays of Imam Baqir (AS) but those who perceive retaliation cited Sakoni's Hadith of Imam Sadiq (AS).

The late Fazil Lankarani also said: "There is a controversy over the revenge of Qisas, who has become voluntarily and intentionally drunk, but it is clear that cautious prevent his retaliation. If you are suspicious of the deliberate of such a person, consider him deliberate. But if he is forced to drink and he was reluctant, there is no doubt that there is no retaliation "(Lankarani, 2000).

Ayatollah Khoyi also said in this regard: Famous jurisprudents are opposed to his retaliation, and some other jurisprudents are not seeking retaliation, but it is unlikely to be said if a person who has been drinking knew that this kind of work led to the loss of his will, and drinking would expose him to murder, then he would be retaliated, and if it is not the case and he does not know his drunkenness will lead to murder and it happened by chance then he is not retaliated (Khoyi, 2013).

\section{7- Lack of Will in Sleep and Blindness}

In all legal systems, the absence of will (sleep, anesthetics, and blindness) will remove the criminal responsibility, and the penalty in such a situation is contrary to criminal justice. From the Islam point of view, this rational rule has been accepted. The well-known Hadith of "Rafa al-ghalam", Those who slept cannot control or decide on their own behavior, therefore, the punishment of such a person is contrary to justice (Horr Ameli, 1989).

Of course, there is a controversy about the level of responsibility, but most jurisprudents refer to this Hadith about punishments, and they believe that there is no responsibility for kids who are asleep or insane (Najafi, 2013), Of course, financial responsibility is not eliminated due to the evidence of the damage done. The asleep and insane are responsible for the financial damages they incurred. In this case the Agheleh has to pay for it since the punishment has been removed.

According to the famous jurists, any murder with no will, has been 
considered as a wrongful crime (Khoyi, 2013) and in the case of artificial asleep or hypnotist, given that a person does not have any willful intention in this situation and he is under the influence of another mysterious force to do some work, then there is no difference from normal sleep. Of course, the one who is hypnotizing, committed a criminal offense by the hypnotized person, is responsible for the crime and can be prosecuted.

If someone knows that he is committing a crime when he is sleeping or he knows that he will be hypnotized in order to commit a crime, he will be responsible for all acts he has done (Madani Kashani, 1990); in addition, he is responsible for all financial damages he incurred.

In the case of the blind, there are two believes among the Imamieh jurists: The first which is attributed to the recent jurists indicates that when the blind is committing murder, his crime is considered as deliberate according to general rules and he is like a person who can see .

Another group believes that his crime is a wrongful one and Agheleh has to pay for it, and if Agheleh cannot afford it he has to pay himself, and if he does not have then "Beyt al- mal" has to pay it because the Muslim lives will not be wasted (Najafi, 2013). It is supported by a Hadith which reads: which means "The deliberate of blind is considered as wrongful one (Horr Ameli, 1989)." "Diyh" firstly has been placed on himself and, if cannot afford it, the ruler will pay for it. There is nothing about the Agheleh.

According to the fact that the deliberate and intention are necessary features of the retaliation for committing "murder" so the same is also true for the blind. So in cases such as pouring deadly poison in someone's food, the blind murderer will be punished because there is a clear deliberate and intention although he is blind. But in cases for example shooting, and incidentally strikes someone and kills him; surely the blind's crime in this example is unintentional and "diyah", has to be paid. Shahid in "Masalek" has taken the first Hadith for the same meaning. The situations in which a person has no criminal responsibility is not limited to the cases mentioned, and it can be said as a general rule that in any situation where a person has no intention and authority and that his action cannot be considered voluntary and intentional, there is no 
criminal liability but there is always civil liability.

\section{8- Obstacles for Delaying Retaliation}

One of the accepted principles of criminal law, which is an integral part of punishment in Islam, is the principle of the personal nature of the punishment, or the same rule which is called" Vezr"; this principle means that every person who commits a crime he himself is responsible for it and his family members and relatives have no criminal responsibility. Now, one of the cases based on the principle of the personal nature of the punishment is the delay in the execution of the pregnant woman's retribution for the survival of the fetus

\section{8- 1- Pregnant Woman Retribution before Giving Birth}

In this case, the convicted ( the Pregnant) will not be punished before giving birth, although her pregnancy is after committing a crime or through adultery, the jurists agree on this matter. But there is a dispute about a woman who deserves retaliation and she claims for pregnancy and has no evidence to prove her claim; in this regard there is a question if it is possible to delay the retaliation or not?

2- Adopt the woman's claim

Famous jurists of the Imamiyah believe that the pregnant woman's saying of being pregnant even without the testimony of the midwives is accepted. Sheikh Tusi also accepts the woman's claim and the delay in retaliation according to Cautious principle". Allameh Helli in "Ghavaed" believes on this rule and Said: the Sheikh Tusi and the late Mohaghegh, the best is caution," he said.

The author of the Javaher under the words of "Mohaghegh" has stated that "precautionary measures" are necessary and must be observed, he writes further: Although the "Mohaghegh, Allamah and Sheikh", considered the caution better, but the appearance of the phrases reveals that caution is obligatory.

Allameh in "Ershad", Fakhr alMohaghaghin, author of " Mu'almeddin", Shahid I, Shahid Thani and Mohaghegh Ardabili, explicitly accepted the woman's claim and delayed the execution of Qisas. Finally, the author of the Javaher also says: "I did not find any objection to this ruling. The famous jurists sought to justify their 
claims for various reasons that can be obtained from jurisprudence books;

2- Those Hadiths that have been made about women's affairs ( edeh and Hayz) and the affirmation of a woman's claim are as follows:

"Zorareh" has narrated from Imam Sadiq(AS) that the Prophet (s) has said: "There are special situation (edeh and Hayz) for women which, whenever they claim, are accepted." The Holy Quran says: There is no reason to hide what God created in their womb." The appearance of the verse indicates that woman' saying is accepted, because the lack of permission to concealment requires the validity of the woman's claim on her pregnancy.

The Hadith of Fazl ibn Hassan Tabarsei from Imam Sadiq (as), which stated in the commentary of the verse. God has given three things to women: "Al- Hayz", "al- Tohr" and "al- Haml". The point of this narrative is that the women' saying is accepted in relation to these three issues. It is for the women to explain this to the fact that their proof goes back to the woman themselves, and only could be known by themselves.

\footnotetext{
8 - rectifying or isolating the effective cause
}

Another reason which is justifying resorting to this rule is the rule of "Daree" which says: As it has been mentioned, the mentioned verse is supporting the affirmation of the woman's claim. So there is a suspicion if the woman can be punished. According to the rule in the case of suspicion it requires to postpone the retaliation till she gives birth.

\section{3- Tanghih Manat ${ }^{8}$}

Another argumentation which can be relied on, is "Tangshan Manat" Since the pregnancy is the same as "Eddeh and Hayz" and in the latter there are several Hadiths which allows the delay so it is possible to delay in case of pregnancy.

\section{8-2- Disapproval of a Woman's Claim}

The author of Javaher has attributed the opposing belief to some of the jurists; among contemporary jurisprudents, the Mohaghegh Khoyi 's view is as the same as to some jurisprudents, as saying: "If the killer claims to be pregnant, according to the famous jurists, the claim will be accepted 
unless there are indications that she is lying in her claim.

There are some other forms which are so problematic and her claim is not acceptable. The following jurists have invoked the following arguments for their claims:

1- The principle is nonpregnancy.

2- Adoption of the woman's claim leads to the loss of the monarchy the right holder for the retribution, while it is not permissible to remove the monarchy with the probability of pregnancy.

3- When a woman has committed a crime, she has been found guilty of retaliation, but in case having fetus, she is skeptical, as a result of this doubt, we are not allowed to put away what has been truly achieved.

Some contemporary jurisprudents, including the Mohaghegh Khoyi have found some drawbacks to the evidences that are as follows;

1- There is no consensus over the claim; Mohaghegh Khoyi states that: If the reason for our claim was consensus, then, as it was examined, there was no consensus here, and as a result, there is no a reason for accepting the woman's saying.
2- The verse of, has been related only to divorced women, since the claim of having fetus by a woman who is pregnant means that she is pregnant and her "eddeh" will be over as she gives birth, and thus the verse does not include the whole women.

Regarding the delay of retaliation in Imamieh's jurisprudential works, two ideas were raised; the first attributed to the famous who believe son delaying punishment because of her claims. The other jurisprudents including "Mohaghegh Khoyi" believes that no delay is allowed and she must be punished on time.

In sum, by examining the arguments of these two views, I (the author) believe that, referring to the appearance of the verse and the principle of, and because of the " cautious" the first idea is right. Of course, it's worth noting that pregnancy today is recognizable in the light of the advances on medical science and other pregnancy tests, and this is not a real debate in the world today.

\section{9- The Death of the Accused or Convicted in the Case of Personal Punishment:}


According to Article 12 of the Islamic Penal Code of Iran, Qisas and Diyas are both considered as punishment, so they are ceased in case of death. According to Article 259, the killer's death date is not effective in the fall of Diyah and Qisas, and there is no difference between the pre-trial prosecution and the trial of the killer or the next. However, the reason for the fall of Qisas and dy'ah in Article 259 is that the punishment for deliberate murder is only retaliation (Khomeini, 1989).

The non-intentional murder is out of the scope of this article (quasiintentional, pure wrongful, and error with fault), and therefore the death of such a murderer will only lead to the loss of "ta'zir", and the Dieh must be paid in this case. There is no difference between natural and abnormal death.

Therefore, if the murderer is killed there is no retaliation and Qisas. In any case, it is necessary to be considered that the death be real and not hypothetical. In the case of suicide, whether the Diye is void or not some of the contemporary jurisprudents, based on the Hadith that the Muslim lives should not be wasted believes that they have to pay Dieh. (Mirhosseini, 2005).
In relation to the "Dera" principle, we have to say that in cases where the occurrence of a crime or its assignment to the accused is in doubt and suspicion, the offense and punishment should be ruled out. The jurisprudential documents of this principle are: Hadiths, consensus and wisdom.

There are two ideas whether the rule applies in Qisas:

A) The opinion of a number of jurists such as Sheikh Tusi, Ghazi IbnBaraj, Shahid Thanai, Majlisi Aval, Imam Khomeini, Makarem Shirazi, Safi Golpayegani and... is applying the principle on Qisas.

B) However, some of the jurists such as author of Javaher, Moghadas Ardebili, Fazil Meghdad, Fazel Lankarani and ...believe that there is no place to apply the principle.

It is much more correct to apply this principle in cases where the proof of Qisas is suspicious and there is no other reason to prove it. Many old and recent jurisprudents have accepted this idea because rescuing a murderer from Qisas due to doubt is better than the killing of an innocent in doubtful cases. Especially in the cases of Qisas, there are alternatives for retaliation, and Diyah is paid (Ismail-Beigi, 2011). 
According to paragraph (a) of Article 237 of the Islamic Penal Code of Iran, First degree murder shall be proven by testimony of two just men; If the witnesses, after giving testimony and issuing the award withdrawing the testimony what would happen? There is a controversy between the jurisprudents as follows:

In the case of withdrawing the testimony after the issuance of Qisas award, including a retribution of lives or injuries, Qisas will be ceased because firstly intentional crime has not been proved by withdrawing the testimony. Secondly, this situation result in doubt and in case of doubt, retaliation is abandoned (Shahid Thani, 1990).

Retaliation in the case of withdrawing the testimony is not forbidden because the punishment for retribution is right of victim heirs and is not ruled out by doubt (Sarakhsi, 1986).

According to Article 1319 of the Iranian Civil Code, if a witness withdraws his testimony, his testimony will not be considered.

The famous belief of the jurisprudents, including the Sonia and the Imamiyah, is as follow:

In the case of intentional murder and injury, withdrawing the testimony of witnesses after the issuing of award and before execution, will cease the retaliation.

In addition, the beneficiary can prosecute witnesses based on Article 650 of the Islamic Penal Code of Iran and in case of lying the witness. (Mirhossini, 2005).

\section{0-Specific Causes of Ceasing Qisas of}

Lives:

The specific causes are those factors which if were met only lead to cease of Qisas.

Proving the murder of two accused with confession of each, if the first withdraw his confession:

Withdrawing of confessions under specific conditions can lead to the cease of Qisas. It means that if one confesses to a person's intentional murder and then the other one admits that murder again, if the first one withdraw both Qisas and Dieh will be removed from both of them.

Before examining the case from legal aspects, it is required to give a brief explanation regarding confessions. According to Article 1259 of the Islamic Penal Code of Iran, confession is "Stating that the others have right against 
you". Therefore, if a statement does not contain both of these two, the confession will not be deemed a perfect one. For example, if someone is charged with deliberate murder, his confession to a wrongful murder is not valid (Dutmarzai, 2016).

Confessions are accepted if the one who is confessing is matured and wise. In addition, intention and authority are also conditions. Not being imbecile is only has to be met on confession of financial issues. So confession of imbecile will be accepted on marriage or divorce and committing the crime.

From the jurisprudents point of view, withdrawing the confession or denying after confession has no effect and confessor is bound to his confession. Because firstly: a wise and mentally matured person who freely admits to state that the other has right against him, it is self-evident that the right in question has actually existed.

Secondly, by making a reasonable confession, a right is created for the benefit of the others, and withdrawing the confession entails the annulment of that right, and this is not only forbidden but also is contrary to the justness which God has entrusted to his servants.
Thirdly: the confession is indicating that something has been established and withdrawing it, is not consistent with its being established (Dutmarzai, 2016).

Fourth: the wise believe that we have to rely on confession without any attention to the denial after that (Marashi Shooshtari, 2007).

Of course, although the principle basically imply the denying after confession is not correct but it is not universal and has an exception. The jurisprudents of both the Imamiyah and the Sonia believe that denying after confession on people rights ( Hagh alnas ) in terms of the right of individuals is not true. In relation to Allah, there is a difference between the Sonia jurisprudents and the Imamieh:

The Sonia jurisprudents believe that denying after confessions can cease the Qisas in case the punishment is not executed because denying confession causes doubts and according to the rule of (Daree) it is rulled out.

Imamiyah jurisprudents consider denying of confessions merely is ceasing of stonning and Qisa in adultery, and in the rest of other crimes they did not effectively consider denial after confession (Shahid Thani, 1990). 
A) If someone confesses to a person's intentional murder and then another person confesses to that murder again, if the first one reject his confession, both of them are released from Qisas or Dieh.

B) Under the aforementioned assumption, the victim's heirs are authorized to choose each one and retribute him to Qisas or asking for dieh (Marashi Shooshtari, 2007). Because Ali ibn Ibrahim's Hadith is weak, and it cannot be compensated for its weakness with the famous act, because the famous act cannot compensate for the weakness of Hadith. (Khoyi, 2013). Secondly, the Hadith is implausible because it seems to be narrated only for the specific case and Imam was not in the position of general statement. Third, the content of the Hadith is opposing to the rule of retaliation and confession (Shahid Thani, 1990).

C) In this hypothesis, victim's heirs can file a lawsuit against one of two people.

D) The victim's heirs can either take revenge on either of the two persons who confess or both, or take Dieh, since the confession of each of the two persons is complete, and such a confession is binding, and just will be removed with the consent of the rightful holder.

\section{Conclusion:}

The great value that Islam has given to human life is well recognized in the significance and valuable principle which are derived from the Shari'a's laws, verses, and Hadiths related to crimes against human integrity. It is rooted in the philosophy of human life that improving human growth and excellence is a necessity. It is obvious that eliminating the human life that is on the path of perfection and excellence is equal to the decline and destruction of the world. Based on this divine insight into human life, Islam has prescribed the Qisas for any anti-human abuses against any human being that violates human physical integrity. Both murder and injuries have been exposed to retaliation.

The present study has concluded as follow:

Ayatullah Khoyi has a special jurisprudence of his own which is different from the other jurisprudents of that period. At the foundations of ijtihad, first, he mentions the science of " Osool" from the main sources, then he considers the science of Rijal as the source of 
ijtihad, and in fact his method of ijtihad is more document-centered. Of course, this is due to the book "Madarek AlAhkam " and the influence of "Seyed Mohammad Mousavi Ameli" and "Shahid Thani". Ayatollah Khoi has supported famous group due to their correct and strong argument in issues like allowing someone to kill himself, murdering someone in drunkenness state and murdering of minor by an adult, threatening someone to murder in case of reluctant and the ban of Qisas of pregnant women. On the issues such as killing wife and stranger being in adultery and inheriting the right of retribution, he has his own consideration basically different from others. Ayatullah Khoyi has been the founder of four of these controversies, and in six cases, his belief has a precedent in the votes of his predecessors. These disparities have caused such different approach to set retaliation as a punishment for the murder of the child by the adult. Other important findings include the fact that most of his fatwa in the field of Qisas have been ignored because of the opposition to the famous group.

\section{References:}

Dutmarzai, Seyyed Mehdi (2016). Argumental Argument, Tehran: Taha Book. Thirty Fourth Edition.

Fadhil Lankarani, Mohammad, Excerpts from Al-Sharia for the description of the Tavrir al-Wislah-al-Qusas (2000). Qom: The Islamic jurisprudential center of the Imams. first edition.

Horr Ameli, Muhammad ibn Hasan, Vasail al-Shia ela Tahsil Masael alSharia, Qom, Al al-Bait (AS) L-ehya alTurath, 1989.

Ibn Idriss, Mohammed ibn Mansour, AlSara'ar al-Hawi, Letahrir al-Fatawi (1990). Qom: Islamic Printing Office, Second Edition.

Ismail-Beigi, Mohammad (2011). Legal Jurisprudence. Volume 3, Tehran: Ghaza Institute for Educational and Research.

Khomeini, Ruhollah, Tahrir al-Waslah (1989). Volume 4. Qom: Al-Ali Press Press. First Printing.

Khoyi, Seyyed Abolghasem (2013). Translation of the Principles of 
Compilation of Al-Mannhaj. Vol. I

Translation by Dr. Akbar Neibzadeh,

Tehran: Khorsandi Publishing, 2013.

Madani Kashani, Reza (1990). Book of Al-Qasas. Qom: Islamic Printing Office. Second Edition.

Marashi Najafi, Shahabuddin, Al-Qusas Ali Zawu al-Quran and al-Sunnah (1995). Qom: Ayatollah Marashi Najafi Library Publishing. First Printing.

Marashi Shooshtari, Mohammad Hassan. (2007). Explanation of the Law of the Prophet and Qisas, 2, 1, Abbasi Shirani, Tehran: Volume. Second Edition.

Mirhosseini, Hasan (2005). Qisas in the Legal System of Islam and Iran. Tehran: Publishing.

Mohaqiq Heli, Najm al-Din Ja'far ibn Hasan, Shira's al-Islam al-Mu'zil al-Hilal and al-Haram (1988). Qom: The Ismaili Institution. Second Edition.

Mohaqiq Heli, Najm al-Din Ja'far ibn Hassan, Al-Mukhtasr al-Nahafi (1997). jurisprudence of al-Amamiyah, Qom:
Al-Mutraqi Al-Diniyah Institute. Sixth Printing.

Najafi, Mohammad Hassan (2013). Translator Jahar Allaham, Qesas, Volume II Tehran: Khorsandi Publishing.

Sarakhsi, Shamsuddin, Al-Matssat (1986). Volume 26. Beirut: Dar AlMarafah.

Shahid Thani, Zayn al-Din al-Bin Ali, Al-Rawzah al-Bhaiyah Faye al-Lama'a al-Dushqiyat (1990). Qom: Bookstore for Judgment. First Edition.

Sheikh Tusi, Mohammad ibn Hasan, AlKhalaf (1980). Qom: Islamic Printing Office.

Sheikh Tusi, Mohammad ibn Hassan Tahzib al-Akkam (1987). Tehran: Dar al-Kabul al-Islam 